example, I have myself obtained evidence that ants are a very important element in the food of Agamid lizards, and Danaine butterflies have been seen to be devoured by certain birds. In this connexion the old adage should be remembered, "One man's meat is another man's poison." It is important also to remember that not even the most enthusiastic supporter of mimicry claims that models are at all times and in all circumstances exempt from being devoured. I have seen the foul-smelling and evil-looking black 'Devil's coach-horse' beetle pulled out from among dead leaves by a wren in a wood and devoured in mid-winter. Edibility is entirely a question of the relative abundance of food : it is not without significance that mimetic resemblances reach their highest development in those parts of the world where insect life is most abundant.

10. Another stumbling-block may be given in Prof. MacBride's words: "It is held that the predatory animals mistake the defenceless species for the dangerous one, and that so the defenceless one escapes."

I do not think it is necessary to suppose this : all that is required for the protection of $B$ is that it should sufficiently resemble $A$ to remind the enemy of an unpleasant experience connected with an attempt to eat $A$. When food is abundant a very slight degree of resemblance to a creature known by previous experience to be unpleasant may save the life of another. This is within the bounds of human experience. Many people intensely dislike worms " because they wriggle so." Why should a wriggling movement be more unpleasant than, for example, the sudden leaping of a frog? Surely, because of man's origin, in countries where an instinctive dread of a snake was a criterion of life and death. It is not that we think worms are snakes, but they remind us of them. This point of view makes it much easier to understand cases where a mimic is much larger or smaller than its model, or where the resemblance is very elementary, or even depends but little upon colour but rather upon some trick of movement or posture.

In all such cases there is nothing in the theory of mimicry produced by selection of variations to prevent further improvement of the resemblances, nor on the other hand, is there any reason why a slight degree of resemblance must be perfected; all that is necessary is that the resemblance should remind an enemy of some previous unfortunate or unpleasing experience. Thus perfect and imperfect mimetic resemblances may exist together.

11. Finally, I would allude to the wonderful deceptive resemblances of the eggs of cuckoos to those of the nest in which they are placed. ${ }^{1}$ In this case the enemy is the parent of the eggs resembled, which are the models. The phenomena are analogous to mimicry; there is a resemblance to something which the enemy will not attack; one theory will explain the evolution of both these classes of deceptive likeness. Can it possibly be claimed that these minutely detailed resemblances between eggs of birds are of a kind which supervene independently in the eggs of cuckoos and host-birds as a reaction to climatic conditions? The answer is, surely, 'No,' and the same answer may be given to the claim that " What happens in real ' mimicry' is apparently that individuals which have reached a certain stage in a reaction to climatic conditions are favoured by natural selection."

${ }^{1}$ See the papers by E. C. Stuart Baker, Proc. Zool. Soc., 1923, p. 277, and F. C. R. Jourdain, ibid., 1925 , 639 . See also presidential addres to Ent. Soc. Lond., Jan. 20,1926, by Prof. F. B. Poulton.

\title{
Diamond Jubilee of the Iron and Steel Institute.
}

TTHE May meeting of the Iron and Steel Institute, 1 to be held this year on May 2 and 3, is of special significance inasmuch as the Institute is celebrating its diamond jubilee. The proposal for the formation of the Institute originated at a meeting of the Northern Iron Trade, held at Newcastle-on-Tyne on Sept. 29, 1868 , and a committee was appointed with the object of giving effect to this suggestion. Mr. Isaac Lowthian Bell (as he then was) took a prominent part in the proceedings from the very beginning, and it was largely through his influence and efforts that the Institute took shape.

A provisional meeting was held in London in February 1869 , at which the Institute was formally constituted, the Duke of Devonshire consenting to accept the position of president for the first two years. The inaugural meeting was held on June 23, 1869 , in the Hall of the Society of Arts, when the noble president delivered a most interesting inaugural address, in which he traced the development of iron and steel manufacture. The next meeting of the Institute was held at Middlesbrough on Sept. 22 and 23 of that year, the first paper, appropriately enough, being by Mr. Isaac Lowthian Bell.

The Institute was by this time fairly formed, the first secretary being Mr. J. Jones and the first treasurer Mr. (afterwards Sir) David Dale. At the end of that year the Institute numbered 292 members; to-day the membership is just over 2700 , and this numerical increase is good evidence that the work of the Institute has met a real need in the iron and steel industry. The object of this, as indeed of all similar technical societies, could scarcely be better stated than it was by the president in his inaugural address, when he declared the object of the Institute to be "the pro- motion of science in its practical applications rather than in its purely intellectual aspects," and it may fairly be said that this principle has been the dominating principle of the Institute.

The jubilee of the foundation of the Institute was celebrated by a banquet in the Guildhall on the evening of May 8, 1919, at which the then president of the Institute, Mr. Eugene Schneider, of the famous Creusot Works, presided, supported by a very distinguished company. As was not unnatural in the spring of 1919 , the conclusion of the War was the thought uppermost in men's minds, and this fact so overshadowed the fact that this was the jubilee meeting of the Iron and Steel Institute that relatively little attention was paid to the fact that the Institute had then attained its half-centenary of existence. On this account the celebration of the diamond jubilee this year is likely to assume an even greater importance than it otherwise would.

It is interesting to note that there are still three members whose membership dates from the inaugural meeting of the Institute in London, namely, Sir Hugh Bell, Bart., himself a past-president and a Bessemer medallist, who joined the Institute at the same time as his father, the late Sir Isaac Lowthian Bell, Bart., who, as already pointed out, took a prominent part in the formation of the Institute; Mr. J. J. Bleckly, of the Pearson and Knowles Coal and Iron Co., Ltd.; and Mr. John Neilson, a nephew of the late James Beaumont Neilson, the inventor of the hot blast, which practically revolutionised the blast furnace practice of the world. The Institute can fairly claim to have counted among its list of members every one of the men who have been distinguished in the iron and steel industry for the last sixty years, and

No. 3104, VoL. 123 ] 
the history of that industry and of its wonderful development is to be found in the Journal of the Iron and Steel Institute.

No one can doubt that the Institute will continue to go forward and prosper along the same lines traced out for it by its founders, which it has so consistently followed throughout the whole sixty years of its existence, and it seems almost superfluous to wish for a continuance of its prosperity for many years to come. This wish will indeed be fervently re-echoed by everyone in Great Britain, seeing that the prosperity of the Iron and Steel Institute is bound up with the prosperity of the iron and steel industry, which in its turn is the foundation of the prosperity of the nation.

\section{The Stone Age in South-Eastern Asia.}

RECENT research appears to point to more or less 1 uniformity in the characteristics of the stone age cultures of south-eastern Asia. Investigations in French Indo-China by MM. Mansuy and Patte and Mlle. Colani in the caves near the Bac-Son massif (Tonkin) yielded a large number of implements which these investigators regarded as relics of the oldest known stone age of Indo-China, classifying them as lower neolithic. Cord-marked pottery was also found, but regarded as belonging to a later phase of the neolithic. Evidence of similar stone age industries has been found in kitchen middens about twenty kilometres from Medan in the east coast province of Sumatra, and on the plains and lower hills of this province at sites always on the banks of rivers.

In the Journal of the Federated Malay States Museums, vol. 12, Part 6, Mr. I. H. N. Evans reviews this material critically in relation to the results of recent excavations in caves in Perak. The hypothesis of the French archæologists is that an early neolithic people, using roughly chipped implements only, came into contact with a people using polished implements, and from them adopted the practice of polishing the edges of their implements. Mr. Evans, however, regards the chipped implements as a truly older palæolithic culture, surviving in association with the forms with polished edges which are proto-neoliths, the latter developing more and more to become a high neolithic culture. In Sumatra, iron weapons of a type still in use in north Sumatra in a layer immediately above that containing bouchers, with no sign of transition, pointed to a very late survival of a palæolithic culture.

In Perak, Mr. Evans, excavating with Dr. P. U. Van Stein Callenfels, of the Archæological Service of the Netherlands Indies, who carried out the investigations in Sumatra, found similar stone age cultures in caves near Lenggong (Upper Perak) and Padang Rengas (Kuala Kangsar). In the latter area the rock shelter, Gua Kerrbau, contained human remains at a depth of 3.18 metres and below. Shellfish formed a large part of the diet of the inhabitants throughout the occupation. Flakes and chips occurred throughout, but the first palæolith was found in deposit $B$, the most common type being the coup de poing of almond shape. The first fragment of a proto-neolith occurred in layer $D$ at a depth of 2.40 metres. The lowest was found at 5.74 metres. The proto-neoliths showed different stages of development. One might be classified as a middle neolith. Grinding stones, grinding slabs, shells, some clearly, others probably, for use as amulets, and pottery in the upper layer were found.

Certain conclusions are offered tentatively: Palæoliths, so-called Sumatra types, and proto-neoliths, are associated throughout; cord-marked pottery belongs to the later stages of palæo-proto-neolithic culture; the makers of proto-neoliths had older types of the neolithic culture as examples; and a palæolithic civilisation making use of 'Sumatra-type' implements spread at a certain period over south-east Asia, reaching even Sumatra, while the palæo-proto-neolithic stage also spread over the same area but did not reach Sumatra.

\section{University and Educational Intelligence.}

LEEDs.-The site is now being cleared for the new block for the Physics Department. The accommodation will include two large laboratories, each about. 5000 square feet in area, and a smaller laboratory for honours students, three lecture theatres for $\mathbf{2 5 0}$, 150 , and 80 students respectively, and about thirty other rooms, the whole occupying a block about 100 feet square and comprising a basement and three floors over. The building is estimated to cost about $\mathfrak{4} 47,400$.

LoNDON.--Notice is given that applications for grants from the Thomas Smythe Hughes Fund for assisting medical research must reach the Academic Registrar, South Kensington, S.W.7, by, at latest, June 15.

ST. ANDrews.--At a meeting of the University Court on April 19, it was intimated that Provost W. Norman Boase, St. Andrews, had gifted to the United College the endowment fund for the institution of a residential entrance scholarship of $£ 100$ a year, tenable for three or four years by an entrant student resident in one of the residential halls of the United College, on conditions similar to those prescribed in the case of the Harkness, Russell, and Patrick Hamilton Entrance Scholarships. As the Patrick Hamilton Scholarship was instituted in commemoration of the quater-centenary of Patrick Hamilton, the Martyr, a former student of the University, so the new scholarship is to be named the Montrose Scholarship in commemoration of the tercentenary of the studentship at St. Salvator's College of the great Marquis of Montrose.

Applicatrons for grants from the Dixon Fund of the University of London, for assistance in scientific investigations, must reach the Academic Registrar of the University, South Kensington, S.W.7, before May 15.

A Busk Studentship in aeronautics, of the value of about $£ 150$ and tenable for one year from Oct. 1 next, for research in aeronautics and specially in stability problems, is being offered. Forms of application, returnable not later than May 12, can be obtained from Prof. B. Melvill Jones, Engineering Laboratory, Cambridge.

A FELcowship of the value of $£ 300$ per annum for research on petroleum problems is being offered by the Institution of Petroleum Technologists. The fellowship will be tenable for one year, with a possible renewal for a further year. Forms of application (returnable by June 1 at latest) are obtainable from the Secretary of the Institution, Aldine House, Bedford Street, W.C.2.

Applications are invited by the trustees of the Dickinson scholarships in connexion with the Manchester Royal Infirmary and the University of Manchester for the following : A research travelling scholarship in medicine value $£ 300$, and a pathology scholarship value $\mathfrak{E 7 5}$. Particulars may be had from the Secretary to the trustees, Royal Infirmary, Manchester. The completed forms must be returned by May 2.

No. 3104, VoL. 123] 